Buana Sains Vol 19 No 2 : 31 - 40, 2019

\title{
UMUR SIMPAN KOPI LENGKUAS INSTAN MENGGUNAKAN METODE ACCELERATED SHELF LIFE TESTING (ASLT) DENGAN PENDEKATAN PERSAMAAN ARRHENIUS
}

\author{
Ratih Yuniastri ${ }^{1}$, Ismawati ${ }^{1}$ dan Dyah Ayu Fajarianingtyas ${ }^{2}$ \\ ${ }^{1}$ Teknologi Hasil Pertanian, Fakultas Pertanian, Universitas Wiraraja \\ ${ }^{2}$ Pendidikan IPA, Fakultas Keguruan dan Ilmu Pendidikan, Universitas Wiraraja
}

\begin{abstract}
Galangal is one of the herbaceous plants that thrive in the Sumenep area and has been utilized by one of the Agro-industries in this area to become an instant galangal coffee product. Galangal processed products are one way to extend the shelf life of galangal. A decrease in quality during product storage can have an impact on the shelf of the product. To provide food safety guarantees for consumers and to support the creation of food independence, information about the shelf life of this product needs to be included. This research is to estimate the shelf life of instant galangal coffee products using the Accelerated Shelf Life Testing (ASLT) method with the Arrhenius approach, using a randomized block design (RBD). An increase in color and water content of instant galangal coffee indicates a decrease in product quality during the storage process. The parameter used to estimate the shelf life of products based on research results is water content. The initial water content of $5,237 \%$ with a critical water content of $18,67 \%$ and based on the Arrhenius equation the rate of water content increase was $\mathrm{K}=$ $656,94 \cdot \mathrm{e}^{-3150,7(1 / \mathrm{T})}$. The shelf life of the instant galangal coffe product under study was 671 days at storage temperature $30^{\circ} \mathrm{C} ; 411$ days at $45^{\circ} \mathrm{C}$ : and 352 days at $50^{\circ} \mathrm{C}$ wit $\mathrm{RH}$ condition maintained at $70 \%$.
\end{abstract}

Keywords: Accelerated Shelf Life Testing (ASLT); Arrhenius; Coffee; Galangal; Shelf life production.

\section{Pendahuluan}

Agroindustri memiliki arti semua proses atau kegiatan industri serta bagian-bagiannya yang berkaitan erat dengan kegiatan pertanian, mencakup proses pengolahan bahan mentah produk pertanian hingga menjadi produk setengah jadi ataupun produk jadi. Tujuannya adalah untuk memenuhi kebutuhan masyarakat serta untuk menambah mutu dari produk pertanian yang dihasilkan.

Lengkuas merupakan salah satu tanaman herbal yang tumbuh subur di Sumenep. Tanaman ini juga telah dimanfaatkan oleh salah satu industri rumah tangga di Sumenep. Salah satu produk olahan yang dihasilkan berupa kopi lengkuas. Kopi ini dibuat dengan mencampurkan bubuk kopi murni dengan sari dari campuran lengkuas-jahe. Kopi lengkuas ini dapat dijadikan sebagai salah satu alternatif produk bagi para penyuka kopi, khususnya masyarakat Madura. Produk kopi lengkuas ini juga telah dikemas dengan kemasan yang cocok, tujuannya menjaga mutu produk selama proses pendistribusian ke pedagang eceran hingga ke konsumen, sehingga dapat menghindari adanya kerusakan pada produk tersebut. Persyaratan mutu bertujuan untuk 
R. Yuniastri, Ismawati, dan D. A. Fajariningtyas/ Buana Sains Vol 19 No 2 : 31-40

melindungi konsumen perlu diperhatikan oleh sebuah industri pangan, khususnya industri rumah tangga. Selain penggunaan kemasan yang cocok, syarat lain yang dapat dicantumkan dalam produk pertanian adalah informasi umur simpan produk tersebut. Informasi ini merupakan salah satu parameter ketahanan produk selama masa penyimpangan yang berkaitan erat dengan pemilihan kemasan yang akan digunakan. Informasi ini juga merupakan bagian dari konsep pemasaran produk (Budijanto, dkk, 2010).

Semua produk pangan rentan mengalami proses deteriorasi, dimulai sejak produk selesai diproduksi yang diakibatkan adanya kontak dengan lingkungan. Jika proses ini terjadi maka akan berdampak terhadap penurunan mutu produk. Penurunan mutu dapat menyebabkan terjadinya penurunan umur simpan produk (Suwita, I.K., Kristianto, Y., dan Purwaningsih, 2013). Jika melewati waktu tersebut, produk bisa dikatakan tidak layak dikonsumsi dikarenakan produk mengalami perubahan-perubahan baik fisik, kimia maupun mikrobiologis seperti kenampaan, citra rasa dan kandungan gizi, bahkan bisa menyebabkan keracunan atau penyakit lain. Umur simpan merupakan faktor penting yang harus diketahui sebelum kopi lengkuas dikonsumsi. Hal ini sesuai dengan (Pemerintah et al., 1999) mengenai Label dan Iklan Pangan yang menyatakan bahwa pencantuman masa kadaluarsa suatu produk pangan pada kemasan diwajibkan bagi setiap produsen makanan dan minuman oleh pemerintah. Kopi lengkuas merupakan salah satu produk olahan kopi, umumnya memiliki kadar air rendah sekitar 4,61\% dan kerusakan bahan pangan yang sering terjadi pada produk olahan kopi adalah peningkatan kadar air dan perubahan warna (Sudibyo, dkk, 2010).

Informasi mengenai umur simpan produk ini belum ditemukan dalam kemasan yang digunakan, sehingga perlu dilakukan studi mengenai pendugaan umur simpan produk kopi lengkuas yang dihasilkan oleh industri rumah tangga ini. Penelitian ini dipandang penting karena untuk mengetahui tingkat ketahanan kopi lengkuas selama masa penyimpanan sebagai bentuk jaminan keamanan pangan bagi para konsumen dan salah satu upaya untuk mendukung terciptanya kemandirian pangan. Penelitian ini dirancang untuk memprediksi umur simpan kopi lengkuas sebagai upaya mendukung ketahanan pangan. Kajian pendugaan umur simpan kopi lengkuas menggunakan metode ASLT dengan pendekatan Arrhenius.

\section{Metode Penelitian}

Penelitian ini dilaksanakan pada bulan April hingga bulan Agustus di Laboratorium Rekayasa Pengolahan Pangan dan Hasil Pertanian Fakultas Pertanian Universitas Wiraraja. Penelitian ini disusun menggunakan metode eksperimen dengan mengadakan pengamatan langsung terhadap objek penelitian, menggunakan Rancangan Acak Kelompok (RAK) dengan 3 kali ulangan. Perkiraan umur simpan dilakukan pada kondisi penyimpangan suhu $30^{\circ} \mathrm{C}, 45^{\circ} \mathrm{C}$, dan $50^{\circ} \mathrm{C}$ dengan kelembaban relative $70 \%$. Sampel yang digunakan adalah produk kopi lengkuas dalam kemasan dengan massa 20 gram. Sampel selanjutnya disimpan selama 8 minggu dalam desikator dan setiap minggunya akan diambil sampel dan dilakukan analisa kadar air dan diuji hasil organoleptiknya. Data yang diperoleh dianalisa menggunakan Anova untuk 
R. Yuniastri, Ismawati, dan D. A. Fajariningtyas/ Buana Sains Vol 19 No 2 : 31-40

menguji interaksi antar parameter yang digunakan yaitu lama penyimpanan dan variasi suhu penyimpanan. Data kadar air kopi lengkuas selama penyimpanan selanjutnya akan digunakan untuk memperkirakan umur simpannya menggunakan metode ASLT dengan model pendekatan Arrhenius.

\section{Bahan dan alat}

Bahan-bahan yang digunakan meliputi kopi lengkuas instan yang diproduksi dan diambil langsung dari agroindustri Pottre Koning di Desa Matanair, Kecamatan Rubaru, Kabupaten Sumenep dengan merek Alomampa. Komposisinya terdiri atas kopi hitam, ekstrak lengkuas, ekstrak jahe, gula.

Alat yang digunakan adalah peralatan untuk menyinpan produk kopi lengkuas instan meliputi inkubator, desikator, dan neraca analitis.

Penelitian perkiraan umur simpan kopi lengkuas instan dilakukan di Laboratorium Pengolahan Prodi Teknologi Hasil Pertanian Universitas Wiraraja. Analisa pendugaan umur simpan yaitu analisa kadar air dilaksanakan di Laboratorium Pengujian Mutu dan Keamanan Pangan, Universitas Brawijaya.

\section{HASIL DAN PEMBAHASAN}

\section{Kadar Air Kopi Lengkuas Instan}

Produk kopi lengkuas instan yang disimpan dalam 3 variasi suhu yang berbeda $\left(30^{\circ} \mathrm{C}, \quad 45^{\circ} \mathrm{C}, \quad\right.$ dan $\left.\quad 50^{\circ} \mathrm{C}\right)$ dilakukan pengujian terhadap kadar airnya. Hasil pengujian kadar air produk kopi lengkuas instan disajikan dalam Tabel 7. Hasil pengujian kadar air berdasar tabel 7 terdapat kecenderungan kadar air yang terus bertambah selama proses penyimpanan. Kenaikan kadar air produk semakin besar seiiring dengan suhu dan kelembaban penyimpanan yang semakin tinggi pula (Widyotomo, Atmawinata and Purwadaria, 2011). Kadar air yang semakin meningkat dapat dikarenakan sifat bahan yang cenderung higroskopis dan sifat permeabilitas bahan kemasan yang digunakan produk, serta tingkat kelembaban udara sekitar atau lingkungan penyimpanan terhadap produk. Akibatnya terjadi adsorbs uap air yang ada di udara (Sudibyo, Hutajulu and Setyadjit, 2010). Peningkatan kadar air produk menyebabkan terjadinya penggumpalan produk dan menandakan terjadinya kerusakan pada produk kopi lengkuas instan.

Kadar air merupakan salah satu parameter mutu dan karakteristik penting dari produk kopi instan (Setyani, S., Subekti, 2017). Clifford (dalam (Sudibyo, Hutajulu and Setyadjit, 2010)) menyatakan bahwa produk kopi instan mengandung kadar air yang tidak lebih dari $4 \%$ pada suhu $20^{\circ} \mathrm{C}$ dengan aktivitas air $\left(a_{w}\right)$ sekitar 0,1-0,3. Besarnya kadar air yang terkandung akan mempengaruhi besarnya nilai aktivitas air $\left(a_{w}\right)$, ketahanan dan stabilitas produk selama masa penyimpanan. Kadar air dijadikan parameter dalam proses pengawasan pengeringan dan ekstraksi kopi.

Data kadar air selanjutnya dilakukan analisa anova untuk melihat interaksi antara suhu penyimpanan dan lama penyimpanan terhadap kadar air. Hasil analisa menunjukkan terdapat perbedaan yang nyata pada parameter suhu dan lama penyimpanan terhadap besarnya kadar air pada taraf signifikansi 0,05 , artinya terdapat interaksi terhadap hasil analisa kadar air. 
R. Yuniastri, Ismawati, dan D. A. Fajariningtyas/ Buana Sains Vol 19 No 2 : 31-40

Tabel 7. Kadar Air Produk Kopi Lengkuas Instan selama Proses Penyimpanan

\begin{tabular}{cccc}
\hline \multirow{2}{*}{ Hari ke- } & \multicolumn{3}{c}{ Kadar Air } \\
\cline { 2 - 4 } & $30^{\circ} \mathrm{C}$ & $45^{\circ} \mathrm{C}$ & $50^{\circ} \mathrm{C}$ \\
\hline 0 & 5.237 & 5.237 & 5.237 \\
7 & 5.293 & 5.307 & 5.373 \\
14 & 5.513 & 5.537 & 5.743 \\
21 & 5.573 & 5.623 & 6.027 \\
28 & 5.613 & 5.730 & 6.357 \\
35 & 5.723 & 5.813 & 6.607 \\
42 & 5.927 & 6.173 & 6.737 \\
49 & 6.117 & 6.380 & 7.220 \\
54 & 6.337 & 6.517 & 7.417 \\
\hline
\end{tabular}

Uji lanjutan dengan Duncan menunjukkan bahwa kadar air pada suhu penyimpanan $50^{\circ} \mathrm{C}$ yang tertinggi dibandingkan pada kadar air kedua produk kopi lengkuas lainnya. Tingginya kadar air pada suhu $50^{\circ} \mathrm{C}$ disebabkan karena adanya peningkatakan permeabilitas bahan kemasan terhadap uap air di udara lingkungan. Semakin tinggi suhu penyimpanan produk maka semakin besar pula sifat permeabilitas bahan kemasan terhadap uap air. Peningkatan sifat permeabilitas bahan kemasan ini menyebabkan semakin banyaknya uap air di udara lingkungan yang melewati permukaan bahan kemasan hingga dapat berinteraksi dengan produk dalam kemasan. Sifat higroskopis serbuk kopi lengkuas instan menyebabkan terjadinya penyerapan uap air yang telah masuk melewati permukaan dan bagian dalam bahan kemasan.

\section{Penentuan Parameter Kritis dan Penentuan Titik Kritis Kopi Lengkuas Instan}

Perubahan pada bahan pangan akan terjadi apabila bahan pangan tersebut disimpan pada kondisi lingkungan tertentu. Adanya penyesuaian bahan pangan terhadap kondisi lingkungan penyimpanan menyebabkan terjadinya perubahan komposisi bahan pangan. Faktor-faktor yang mempengaruhi terjadinya perubahan ini menjadi dasar penentuan titik kritis dari masa simpan produk (Herawati, 2008). Penentuan parameter kritis yang digunakan dalam penelitian ini ditetapkan berdasarkan penurunan mutu selama waktu penyimpanan produk. Parameter yang diamati meliputi kadar air dan warna produk kopi. Parameter kritis ditentukan berdasarkan perubahan mutu yang terjadi paling cepat selama proses penyimpanan (Sudibyo, Hutajulu and Setyadjit, 2010).

Hasil pengamatan diperoleh secara umum terjadi peningkatan kadar air produk kopi lengkuas instan selama penyimpanan. Peningkatan kadar air pada penyimpanan suhu $30^{\circ} \mathrm{C}$ terjadi dari $5,237 \%$ hingga menjadi 6,337\%; pada penyimpanan suhu $45^{\circ} \mathrm{C}$ terjadi peningkatan dari 5,237\% hingga 6,517\%; sedangkan pada penyimpanan suhu $50^{\circ} \mathrm{C}$ peningkatan terjadi dari 5,237\% hingga $7,417 \%$. Peningkatan terjadi pada ketiga kondisi penyimpanan.

Hasil pengamatan pada parameter warna kopi lengkuas instan 
R. Yuniastri, Ismawati, dan D. A. Fajariningtyas/ Buana Sains Vol 19 No 2 : 31-40

selama masa penyimpanan menunjukkan terjadinya peningkatan perubahan tingkat kecerahan produk pada minggu pertama hingga minggu ketiga. Tingkat kecerahan kopi lengkuas instan setelah minggu ketiga relative tetap.

Berdasar hasil pengamatan, parameter mutu yang digunakan untuk menentukan parameter kritis produk adalah kadar air. Kadar air dipilih karena terjadi peningkatan kadar air selama penyimpanan, penambahan ini menyebabkan produk lebih cepat mengalami kerusakan, dibandingkan dengan tingkat kecerahan yang relatif tetap. Produk kopi lengkuas instan berupa bubuk yang memiliki sifat mudah mengabsorp air, jika kondisi ini berlangsung secara terus-menerus, maka pada akhirnya produk akan mencapai titik kritisnya. Titik kritis produk ini ditandai dengan terjadinya penggumpalan yang berakibat pada penolakan produk oleh konsumen. Seperti penjelasan (Yusa, 2014; Ferdiansyah et al., 2017) beberapa ciri terjadinya kerusakan produk yaitu adanya penurunan kerenyahan atau kekerasan, terjadinya penggumpalan atau peningkata kelengketan.

Parameter mutu kritis yang digunakan adalah kadar air, sehingga akan diperoleh kadar air kritis sebagai data titik kritis mutu dari produk kopi lengkuas instan. Sebelum dilakukan pengujian kadar air kritis, terlebih dahulu dilakukan uji organoleptik terhadap produk kopi lengkuas instan. Produk yang pertama kali mengalami penolakan oleh konsumen lebih dari $50 \%$ panelis dinyatakan sebagai kopi lengkuas instan yang telah mengalami kerusakan (Labuza, 1982; Sudibyo, Hutajulu and Setyadjit, 2010). Kemudian dilakukan analisis terhadap kadar air produk. Data yang diperoleh dinyatakan sebagai kadar air kritis kopi lengkuas instan yaitu sebesar $18,67 \%$.

\section{Penentuan Umur Simpan Kopi Lengkuas Menggunakan Metode ASLT dengan Pendekatan Arrhenius}

Penentuan umur simpan kopi lengkuas dilakukan menggunakan metode akselerasi dengan parameter kadar air. Berdasar pendekatan Arrhenius, perubahan mutu produk sangat dipengaruhi oleh faktor suhu. Percepatan dengan faktor suhu ini dilakukan pada beberapa suhu tingkatan penyimpanan di atas suhu ruang, tujuannya untuk percepatan pencapaian nilai kadar air kritis.

Berdasar penentuan parameter titik kritis dan hasil pengamatan selama pelaksanaan, diperoleh nilai kadar air kritis produk kopi lengkuas sebesar 18,67\%. Data kadar air pada tiga kondisi suhu penyimpanan yang dianalisis menggunakan regresi linier yaitu hubungan antara selang waktu penyimpanan dan peningkatan kadar air pada ketiga suhu penyimpanan $30^{\circ} \mathrm{C}$, $45^{\circ} \mathrm{C}$, dan $50^{\circ} \mathrm{C}$. Grafik regresi linier disajikan pada gambar 1, gambar 2 dan gambar 3 . 


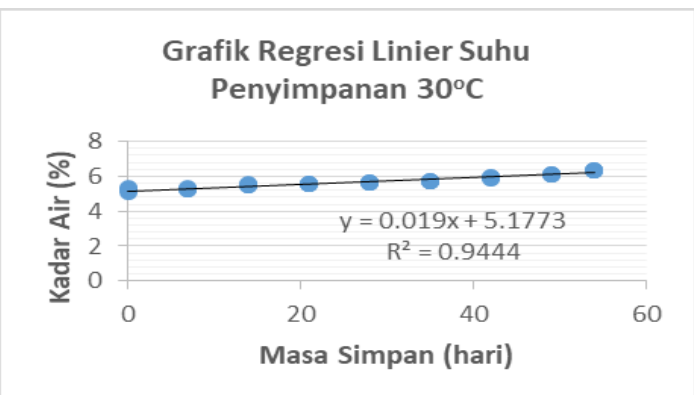

Gambar 1. Regresi Linier peningkatan kadar air produk kopi lengkuas instan pada suhu penyimpanan $30^{\circ} \mathrm{C}$.

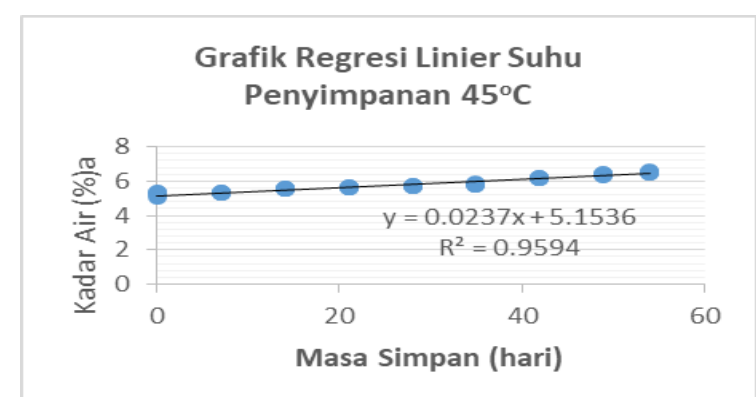

Gambar 2. Regresi Linier peningkatan kadar air produk kopi lengkuas instan pada suhu penyimpanan $45^{\circ} \mathrm{C}$.

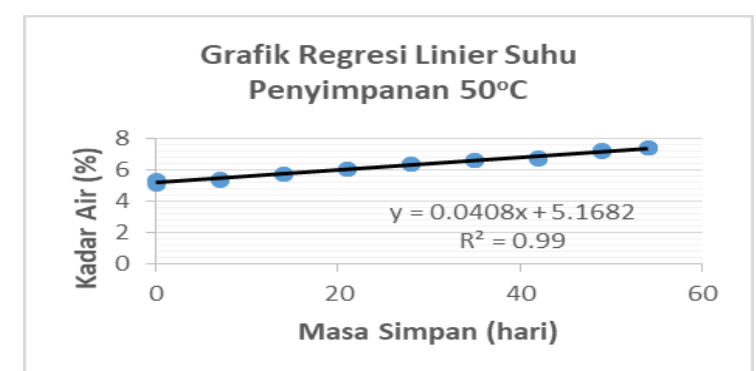

Gambar 3. Regresi Linier peningkatan kadar air produk kopi lengkuas instan pada suhu penyimpanan $45^{\circ} \mathrm{C}$.

Gambar 1,2 dan 3 menunjukkan adanya tren atau kecenderungan peningkatan nilai kadar air selama selang waktu penyimpanan di masing-masing suhu penyimpanan. Persamaan garis lurus yang diperoleh pada ketiga suhu penyimpanan yaitu (gambar 1) untuk suhu $30^{\circ} \mathrm{C}$ diperoleh persamaan kurva y $=0,019 \mathrm{x}+5,177$ dengan $\mathrm{R}^{2}=0,944$; (gambar 2) untuk suhu $45^{\circ} \mathrm{C}$ diperoleh persamaan kurva $\mathrm{y}=0,024 \mathrm{x}+5,153$ dengan $\mathrm{R}^{2}=0,959$; (gambar 3) untuk suhu $50^{\circ} \mathrm{C}$ diperoleh persamaan kurva y $=0,041 \mathrm{x}+5,168$ dengan $\mathrm{R}^{2}=0,99$. Dari masing-masing persamaan regresi linier akan diperoleh besarnya slope atau kemiringan. Nilai slope ini merupakan nilai $\mathrm{k}$, yaitu untuk suhu $30^{\circ} \mathrm{C}$ sebesar $\mathrm{k}_{1}$ $=0,019$ dan $\ln \mathrm{k}_{1}=-3,963$; untuk suhu $45^{\circ} \mathrm{C}$ sebesar $\mathrm{k}_{2}=0,024$ dan $\ln \mathrm{k}_{2}=-3$, 730 ; sedangkan untuk suhu $50^{\circ} \mathrm{C}$ sebesar $\mathrm{k}_{3}=0,041$ dan $\ln \mathrm{k}_{3}=-3,194$. Nilai slope bertambah seiring meningkatnya suhu penyimpanan produk (Pranoto et al., 2012). Selanjutnya dibuat plot grafik 
R. Yuniastri, Ismawati, dan D. A. Fajariningtyas/ Buana Sains Vol 19 No 2 : 31-40

berdasar persamaan Arrhenius yaitu hubungan antara besarnya nilai $\ln \mathrm{k}$ dengan nilai $1 / \mathrm{T}$ dalam Kelvin. Nilai ln $\mathrm{k}$ sebagai ordinat sumbu $\mathrm{Y}$ dan nilai $1 / \mathrm{T}$ sebaga ordinat sumbu $\mathrm{X}$. Plot grafik Arrhenius kopi lengkuas instan disajikan pada Gambar 4.

Hasil analisis plot nilai $1 / \mathrm{T}$ dengan nilai $\ln \mathrm{K}$ diperoleh persamaan regresi linier $\mathrm{y}=-3150,7 \mathrm{x}+6,4876$ dengan $R^{2}=0,756$. Nilai kemiringan (slope) dalam persamaaan Arrhenius adalah nilai $-\mathrm{E} / \mathrm{R}$, sehingga besarnya energy aktivasi dari kopi lengkuas instan dapat dihitung sebagai berikut: -E/R = 3150,7 K dengan $\mathrm{R}$ adalah konstanta gas $\mathrm{R}$ yang nilainya $1,986 \mathrm{kal} / \mathrm{mol} . \mathrm{K}$, sehingga diperoleh besarnya $\mathrm{E}=-3150,7$ $\mathrm{K} \times 1,986 \mathrm{kal} / \mathrm{mol} . \mathrm{K}$ menghasilkan $\mathrm{E}=$
6257,29 $\mathrm{kal} / \mathrm{mol}$. E adalah energy aktivasi dari kopi lengkuas instan, yaitu besarnya energy minimum yang dibutuhkan untuk menghasilkan suatu reaksi. Artinya energy minimal yang dibutuhkan produk kopi lengkuas untuk menghasilkan reaksi perubahan kadar air yaitu sebesar 6257,29 $\mathrm{kal} / \mathrm{mol}$. Nilai intersep dari persamaan regresi linier atau perpotongan kurva dengan sumbu y merupakan nilai ln Ko pada persamaan Arrhenius. Besarnya nilai intersep (ln Ko) yaitu 6,4876 dan diperoleh $\mathrm{Ko}=656,94$. Nilai E/R dan nilai Ko telah diperoleh sehingga laju peningkatan kadar air berdasar persamaan Arrhenius pada produk kopi lengkuas instan yaitu 656,94 .

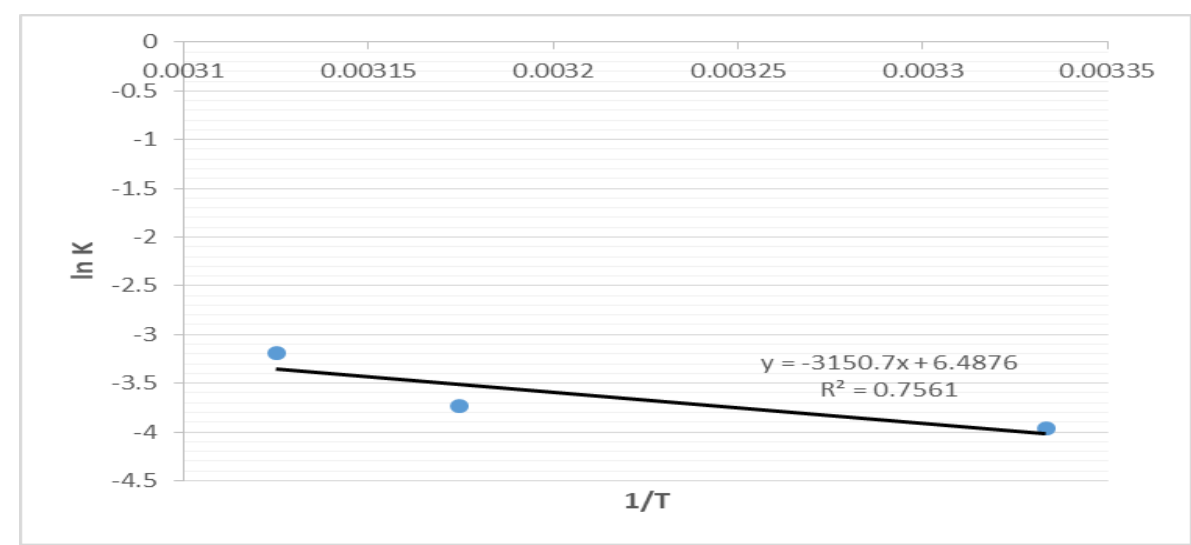

Gambar 4. Grafik hubungan antara nilai 1/T (K) dengan nilai ln K pada produk kopi lengkuas instan.

$$
\mathrm{K}=\mathrm{Ko} . \mathrm{e}^{-\mathrm{E} / \mathrm{RT}} \text { atau } \mathrm{K}=656,94 \cdot \mathrm{e}^{-\mathrm{E} / \mathrm{RT}} \text {. }
$$

Berdasar persamaan tersebut, maka besarnya laju peningkatan kadar air pada masing-masing suhu penyimpanan dapat dihitung sebagai berikut:

Untuk suhu $30^{\circ} \mathrm{C}$ atau $303 \mathrm{~K}$

Maka $\mathrm{K}=656,94 \cdot \mathrm{e}^{-3150,7 / 303}=656,94 \times 3,048 \times 10^{-5}=2002,35 \times 10^{-5}=200,24 \times 10^{-4}$ Untuk suhu $45^{\circ} \mathrm{C}$ atau $318 \mathrm{~K}$

Maka $\mathrm{K}=656,94 \cdot \mathrm{e}^{-3150,7 / 318}=656,94 \times 4,978 \times 10^{-5}=3270,24 \times 10^{-5}=327,02 \times 10^{-4}$ Untuk suhu $50^{\circ} \mathrm{C}$ atau $323 \mathrm{~K}$

Maka K $=656,94 \cdot \mathrm{e}^{-3150,7 / 323}=656,94 \times 5,803 \times 10^{-5}=3812,22 \times 10^{-5}=381,22 \times 10^{-4}$ 
R. Yuniastri, Ismawati, dan D. A. Fajariningtyas/ Buana Sains Vol 19 No 2 : 31-40

Selanjutnya umur simpan produk
kopi lengkuas instan dihitung
menggunakan persamaan Arrhenius ordo
pertama dan hasil perhitungan laju
peningkatan kadar air produk
menggunakan
persamaan:
t(umur simpan) $=\frac{\text { (nilaikadar airkritis-nilaikador air awal) }}{\text { lajupeningkatankodarair }}$

\section{Menggunakan}

persamaan tersebut selanjutnya dihitung umur simpan produk kopi lengkuas instan dengan nilai kadar air awal 5,237\% dan nilai kadar air kritis 18,67\% serta nilai laju peningkatan kadar air masing-masing suhu penyimpanan, maka diperoleh:

Suhu $30^{\circ} \mathrm{C}$ atau $303 \mathrm{~K}$

$\mathrm{t}=(18,67 \%-5,237 \%) / 200,24 \times 10^{-4}=671$ hari

Suhu $45^{\circ} \mathrm{C}$ atau $318 \mathrm{~K}$

$\mathrm{t}=(18,67 \%-5,237 \%) / 327,02 \times 10^{-4}=411$ hari

Suhu $30^{\circ} \mathrm{C}$ atau $303 \mathrm{~K}$

$\mathrm{t}=(18,67 \%-5,237 \%) / 381,22 \times 10^{-4}=352$ hari

Semakin besar atau meningkat suhu penyimpanan, umur simpan produk kopi lengkuas instan semakin pendek. Umur simpan produk kopi lengkuas instan pada suhu $30^{\circ} \mathrm{C}$ selama 671 hari; suhu penyimpanan $45^{\circ} \mathrm{C}$ selama 411 hari; dan suhu penyimpanan $50^{\circ} \mathrm{C}$ selama 352 hari.

\section{Kesimpulan}

Peningkatan warna dan kadar air kopi lengkuas instan menunjukkan terjadinya penurunan mutu produk selama proses penyimpanan. Parameter yang digunakan untuk memperkirakan umur simpan produk berdasar hasil penelitian adalah kadar air. Kadar air awal sebesar 5,237\% dengan kadar air kritis $18,67 \%$ dan berdasar persamaan Arrhenius diperoleh laju peningkatan kadar air sebesar $\mathrm{K}=656,94 \cdot \mathrm{e}^{-3150,7(1 / \mathrm{T})}$. Umur simpan produk kopi lengkuas instan yang diteliti yaitu 671 hari pada suhu penyimpanan $30^{\circ} \mathrm{C}$; 411 hari pada suhu penyimpanan $45^{\circ} \mathrm{C}$; dan 352 hari pada suhu penyimpanan $50^{\circ} \mathrm{C}$ dengan kondisi RH yang dijaga pada $70 \%$.

\section{Ucapan Terima Kasih}

a. Direktorat Riset dan Pengabdian Masyarakat (DRPM) Kementrian Ristek Dikti yang telah mendanai penelitian ini melalui Program Penelitian Dosen Pemula.

b. Teman-teman dosen dan mahasiswa Program Studi Teknologi Hasil Pertanian Universitas Wiraraja yang telah mendukung dan membantu pelaksanaan penelitian.

\section{Daftar Pustaka}

Budijanto, S., Boing, A. and Dwi, Y. 2010. Penentuan Umur Simpan Tortilla Dengan Metode Akselerasi Berdasarkan Kadar Air Kritis Serta Pemodelan Ketepatan Sorpsi Isothermalnya. Teknologi dan Industri Pangan, XXI(2), pp.165170.

Ferdiansyah, F. et al. 2017. Pengaruh Metode Nanoenkapsulasi terhadap Stabilitas Pigmen Karotenoid dan Umur Simpan Minyak dari Buah Merah ( Pandanus conoideus L ). Influence of Nanoencapsulation Method on The Stability of Carotenoid Pigment and Shelf life. 37(4). 
R. Yuniastri, Ismawati, dan D. A. Fajariningtyas/ Buana Sains Vol 19 No 2 : 31-40

Herawati, H. 2008 Penentuan umur simpan pada produk pangan. Jurnal Litbang Pertanian, 27(4), pp. 124-130.

Labuza, T. 1982 Open shelf Life Dating Of Food. West Port CT: Food and Nutrition Press.

Pranoto, Y. et al. 2012. Carboxymethyl Cellulose Menggunakan Metode Accelerated Shelf-Life Test ( Aslt), 32(3). pp. 301-307.

Sudibyo, A., Hutajulu, T. and Setyadjit. 2010. Pendugaan Masa Simpan Produk Kopi Instan Menggunakan studi Penyimpanan Yang Diakselerasi Dengan Model Kinetika Arrhenius. Journal of Agro-Based Industry, 27(1), pp. 12-24.

Suwita, I.K., Kristianto, Y., dan Purwaningsih, F. 2013 'Pendugaan Umur Simpan Sirup Temulawak (Curcuma xanthorrhiza Roxb), Madu dan Ekstrak Ikan Gabus ( Ophiocephalus striatus) dengan Model Arrhenius dan Model Q10 Self Life Prediction. Jurnal Agromix, 2(September), pp. 18-35.

Widyotomo, S., Atmawinata, O. and Purwadaria, H. K. 2011. Karakterisasi Isoterm Sorpsi Air Biji Kopi (Water soption isotherms characterization of green coffee beans) by BET and GAB models. 31(3), pp. 228-236.

Yusa, N. M. 2014. Karakteristik Isotermis Sorpsi Air Dan umur simpan Ledok. Instan Moisture Sorption Isotherm Characteristics and Shelf Life. 34(1), pp. 29-35. 
R. Yuniastri, Ismawati, dan D. A. Fajariningtyas/ Buana Sains Vol 19 No $2: 31-40$ 